\title{
Influence of Selected Organic Manures on the Seed Germination and Seedling Growth of Cluster Bean (Cyamopsis tetragonoloba (L.) Taub)
}

\author{
Saritha, $\mathbf{M}^{1}$, Vijayakumari, $\mathbf{B}^{1}$, Hiranmai Yadav $\mathbf{R}^{2}$, and Kandari $\mathbf{L S}^{2^{\star}}$ \\ ${ }^{1}$ Department of Botany, Avinashilingam University for Women Coimbatore - 641 043, Tamil Nadu, India \\ ${ }^{2}$ School of Natural Resources Management and Environmental Sciences, College of Agriculture and \\ Environmental Sciences, Haramaya University, Post Box No: 337, Dire Dawa, Ethiopia
}

\begin{tabular}{|c|c|}
\hline Abstract & Article Information \\
\hline $\begin{array}{l}\text { Organic agriculture is a sustainable and environment friendly production system that offers } \\
\text { a wide range of economic, environmental, social and cultural benefits. In the wake of the } \\
\text { resources constraints for external farm inputs faced by farmers in developing countries, } \\
\text { sustainable agriculture that relies on renewable local or farm resources presents desirable } \\
\text { options for enhancing agricultural productivity. The present study was focused on the } \\
\text { influence of organic manures such as panchagavya, micro-herbal fertilizer, biofertilizer, } \\
\text { humic acid and farm yard manure (FYM) on the germination and biometric parameters of } \\
\text { cluster bean (Cyamopsis tetragonoloba (L.) Taub). The panchagavya soil treatment } \\
\text { recorded best germination on } 7^{\text {th }} \text { and } 21^{\text {st }} \text { days after sowing and in panchagavya leaf } \\
\text { treatment on } 14^{\text {th }} \text { and } 28^{\text {th }} \text { DAS. The root length on } 60^{\text {th }} \text { day, shoot length on } 30^{\text {th }}, 60^{\text {th }} \text { and } \\
90^{\text {th }} \text { day root volume on } 60^{\text {th }} \text { day, number of leaves on } 60^{\text {th }} \text { day, dry weight on } 60^{\text {th }} \text { day, } \\
\text { fresh weight on } 60 \text { and } 90^{\text {th }} \text { day were improved by panchagavya leaf treatment compared } \\
\text { to control. The panchagavya soil treatment improved the root length on } 30^{\text {th }} \text { day, root } \\
\text { volume on } 30^{\text {th }} \text { day, fresh weight on } 30^{\text {th }} \text { day and vigour index on } 30^{\text {th }} \text {, } 60^{\text {th }} \text { and } 90^{\text {th }} \text { day in } \\
\text { comparison to other treatments. The panchagavya leaf and soil treatment improved } \\
\text { number of leaves on } 30^{\text {th }} \text { day. The dry weight on } 30^{\text {th }} \text { day was influenced by FYM, } \\
\text { panchagavya soil treatment and panchagavya leaf treatment. The FYM improved root } \\
\text { length, number of leaves, root volume and dry weight on } 90^{\text {th }} \text { day. It was observed from the } \\
\text { study that the treatment containing panchagavya (or) biofertilizer (rhizobium) (or) FYM } \\
\text { could be an ideal and suitable potting mixture for better seedling and crop production in } \\
\text { cluster bean }\end{array}$ & 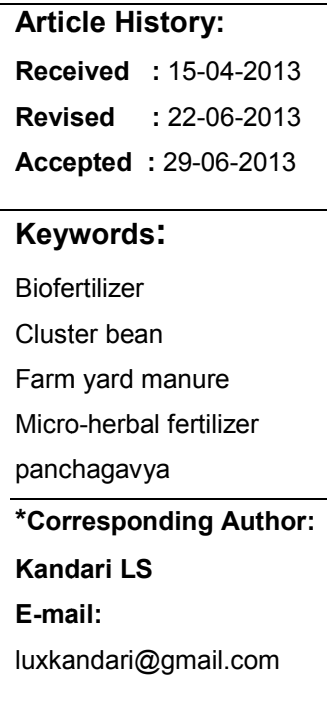 \\
\hline
\end{tabular}

\section{INTRODUCTION}

Organic farming is gaining gradual momentum across the world. Growing awareness of health and environmental issues in agriculture has demanded production of organic food, which is emerging as an attractive source of rural income generation (Bhattacharya and Chakraborty, 2005). There is no doubt that "Green Revolution", during late 1960s in India, brought about a spectacular increase in agricultural production. In fact, during the era of "Green Revolution", introduction of high yielding varieties of crops, extension of irrigated areas, use of chemical fertilizers and pesticides and enhancing of cropping intensity, made the country selfsufficient in food production. In the "Green Revolution" process, however, the use of organic manures, which was hitherto the main practice in
Indian agriculture, diminished considerably (Gupta et al., 2005). Chemical fertilizers are very expensive compared to organic manures. The harmful effects of chemical based farming such as accumulation of excessive amount of nitrate in the underground water, occurrence of a sharp decline in the ground water level and its contamination with heavy metals, deposition of phosphate along with nitrate in the aquatic ecosystems, presence of pesticidal residues in various food stuffs, caused a number of problems in human beings, animals and plants. Rise in resistance of pests to chemical pesticides, occurrence of multi-nutrient deficiencies in soils, thereby resulting into an overall decline in their production capacity under intensive fertilizer use, are the other deleterious effects created by the 
Saritha et al.,

"Green Revolution". Organic manure improves soil conservation, soil ecology and the environment. The addition of organic nutrients to soil is a pre-requisite for achieving increased organic matter, crop productivity and soil biological activity. All this forced us to return to "Organic Farming".

Compost prepared from organic wastes such as leaf litter, sugarcane trash, rice husk and saw dust using millipedes were found to be a promising technology for utilization of organic wastes and converting them into organic manure. This could be a promising technology for reducing the usage of synthetic fertilizers (Karthigeyanm and Alagesan, 2011). Bindhu et al., 2013 have also reported that the use of biodynamic compost could be ideal and suitable organic mixture for soybean.

Cyamopsis tetragonoloba (Cluster bean) belonging to the family leguminosae is grown as a vegetable for human consumption, as a cover crop, green manure and as forage for cattle. The plant is drought resistant. Young pods are eaten like string beans, or may be dried, salted or fried in oil until crisp. Mature pods cooked as a vegetable. Leaves are eaten to cure night-blindness. Green pods contain protein, fat, fiber, carbohydrate, Cadmium (Ca), Phosphorus (P), Iron (Fe), Vitamin A and Vitamin C. Therefore, this study was carried out to assess the efficacy of panchagavya (comprises cow dung, cow's urine, cow's milk, curd and ghee), micro -herbal fertilizer (leaf extracts of Cajanus cajan, Azadirachta indica, and Moringa oleifera), biofertilizer (Rhizobium), humic acid (microbial degradation of plant and animal debris) and FYM (decomposed mixture of cattle dung) on the morphometric attributes of cluster bean.

\section{MATERIALS AND METHODS}

The experiment was conducted at Avinashilingam University, Coimbatore, Tamil Nadu, India to assess the manurial value of panchagavya, micro-herbal fertilizer, biofertilizer, humic acid and FYM in various recommended doses on the test crop C. tetragonoloba.

\section{Seeds and Soil Collection}

Red sandy loam soil was used for the experiment. Seeds of $C$. tetragonoloba were bought from Tamil Nadu Agricultural University, Coimbatore, Tamil Nadu, India.

\section{Panchagavya}

Panchagavya consists of five products viz. cow dung, cow's urine, milk, curd and ghee. Cow dung $(1.75 \mathrm{~kg})$ and cow ghee $(250 \mathrm{~g})$ were added to a wide mouthed plastic can, mixed the two ingredients thoroughly both in morning and evening hours, and
Sci. Technol. Arts Res. J., April-June 2013, 2(2): 16-21

kept it for 3 days. After 3 days, cow's urine (2.5 $\ell$ ) and water $(2.5 \ell)$ were mixed into the can and kept it for 15 days with regular mixing both in morning and evening hours. After 15 days Cow milk $(0.75 \ell)$, Cow curd $(0.50 \ell)$, Tender coconut water $(0.75 \ell)$, Jaggery $(750 \mathrm{~g})$ and well ripened poovan banana (3 Nos.) were added to the plastic can and mixed well. The container was kept open under shade. The content was stirred twice a day both in morning and in evening hours. The panchagavya stock solution was ready after 30 days. It was kept in the shade and covered with a wire mesh or plastic mosquito net to prevent houseflies from laying eggs and the formation of maggots in the solution.

\section{Preparation of Micro-Herbal Fertilizer}

In order to give direct feeding of major nutrients of nitrogen, phosphorus and potassium (NPK) for the crops, leaf extracts, of the following commonly grown green manure crops were selected. Cajanus cajan for nitrogen, Azadirachta indica for phosphorus and Moringa oleifera for potassium content were used for herbal fertilizers (Gopalan et al., 2000).

\section{Biofertilizer}

Rhizobium has been widely and extensively used as a biofertilizer because of its proven ability to fix and contribute nitrogen for the benefit of the leguminous host plants.

\section{Humic Acid}

Humic acids are the end product of microbial degradation of plant and animal debris and are one of the most important constituents of fertile soils. Humic acid contains Sulfur, Nitrogen and Phosphorus in varying amounts. It also contains metals such as $\mathrm{Ca}, \mathrm{Mg}, \mathrm{Cu}, \mathrm{Zn}$ etc. The application of humic acid favourably influences the soil enzymic activity and ultimately leads to increased soil fertility and better crop growth.

\section{Farmyard Manure}

Farmyard manure is the traditional manure and is mostly readily available to the farmers. It is the decomposed mixture of cattle dung and urine with straw and litter used as bedding material and residues from the fodder fed to the cattle. The residual effect of FYM restores the physicochemical properties of soil. Well rotten FYM contains $\quad 0.4-1.5 \% \mathrm{~N}, \quad 0.3-0.9 \% \quad \mathrm{P}_{2} \mathrm{O}_{5} \quad$ and $0.3-1.9 \% \mathrm{~K}_{2} \mathrm{O}$.

With the above organic manures, different treatments were made in completely randomized design with three replications. 
Saritha et al.,

\section{Treatment Details}

$\mathrm{T}_{0^{-}}$Control

$\mathrm{T}_{1-}$ Farm Yard Manure (FYM) $35 \mathrm{~g} / \mathrm{pot}$

$\mathrm{T}_{2^{-}}$Humic acid (2 percent/pot)

$\mathrm{T}_{3^{-}} \quad$ Panchagavya leaf treatment (10 percent/pot)

$\mathrm{T}_{4^{-}}$Panchagavya soil treatment (10 percent/pot)

$\mathrm{T}_{5}-$ Microherbal fertilizer $(20 \mathrm{~g} / \mathrm{pot})$

$\mathrm{T}_{6^{-}}$Biofertilizer (18 g/pot)

\section{Biometrical Observation}

Germination percentage was calculated on $7^{\text {th }}$, $14^{\text {th }}, 21^{\text {th }}$, and $28^{\text {th }}$ day (days after showing). Biometric parameters analyzed on $30^{\text {th }}, 60^{\text {th }}$ and $90^{\text {th }}$ day were root length, shoot length, root volume, number of leaves per plant, fresh weight of plant, dry weight of plant and vigour index.
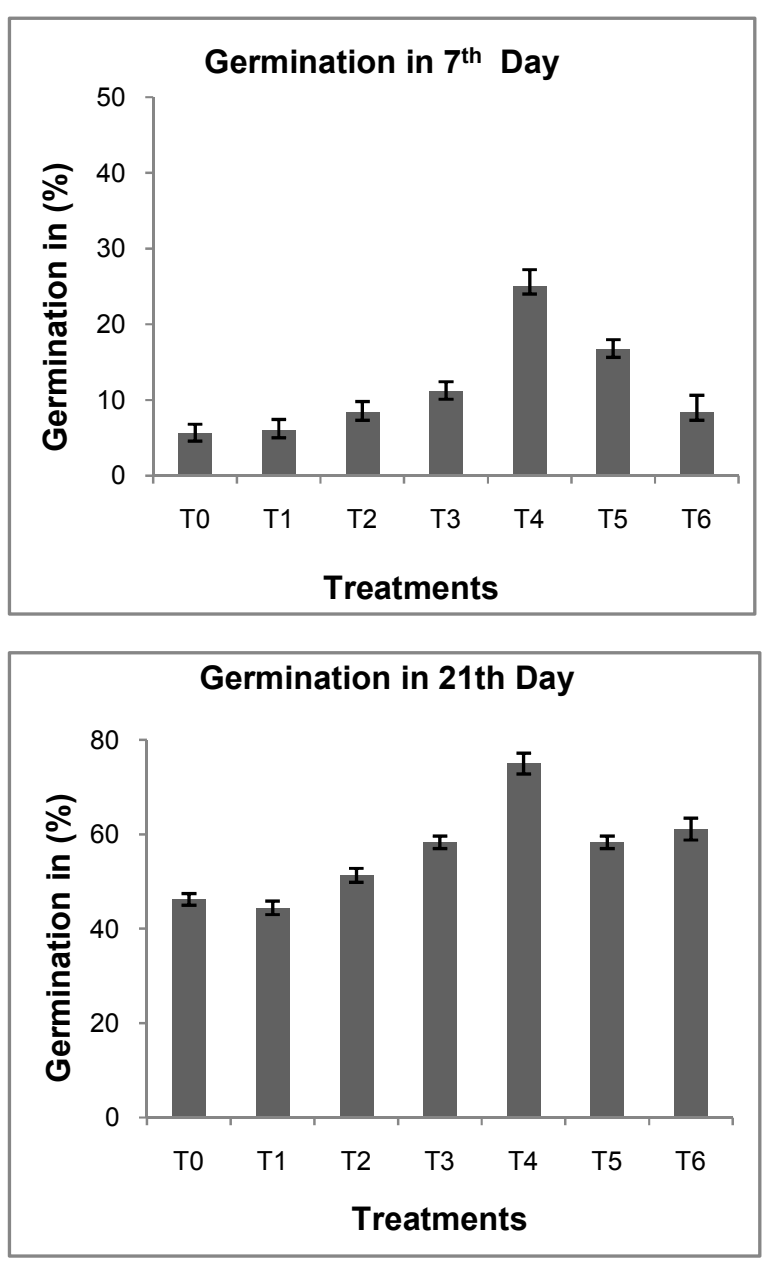

Sci. Technol. Arts Res. J., April-June 2013, 2(2): 16-21

\section{Statistical Analysis}

The data obtained from various biometrical parameters were subjected to statistical analysis by one way ANOVA method. Based on the results inferences were drawn. For the significant treatment differences, critical differences were worked out.

\section{RESULTS AND DISCUSSIONS Germination Percentage}

The germination percentages were recorded on $7^{\text {th }}, 14^{\text {th }}, 21^{\text {st }}$ and $28^{\text {th }}$ day. In seven days the highest germination was recorded under $\mathrm{T}_{4}$ treatment $(25 \%)$ followed by $T_{5}$ (16.67) on $14^{\text {th }}$ days. The highest germination percentage were recorded as highest in $\mathrm{T}_{4}$ and $\mathrm{T}_{3}$ treatment on $21^{\text {st }}$ and $28^{\text {th }}$ day compared to control (Figure 1). Javed and Panwar (2013) observed that use of vermicompost had highest seed germination compared to other treatments.
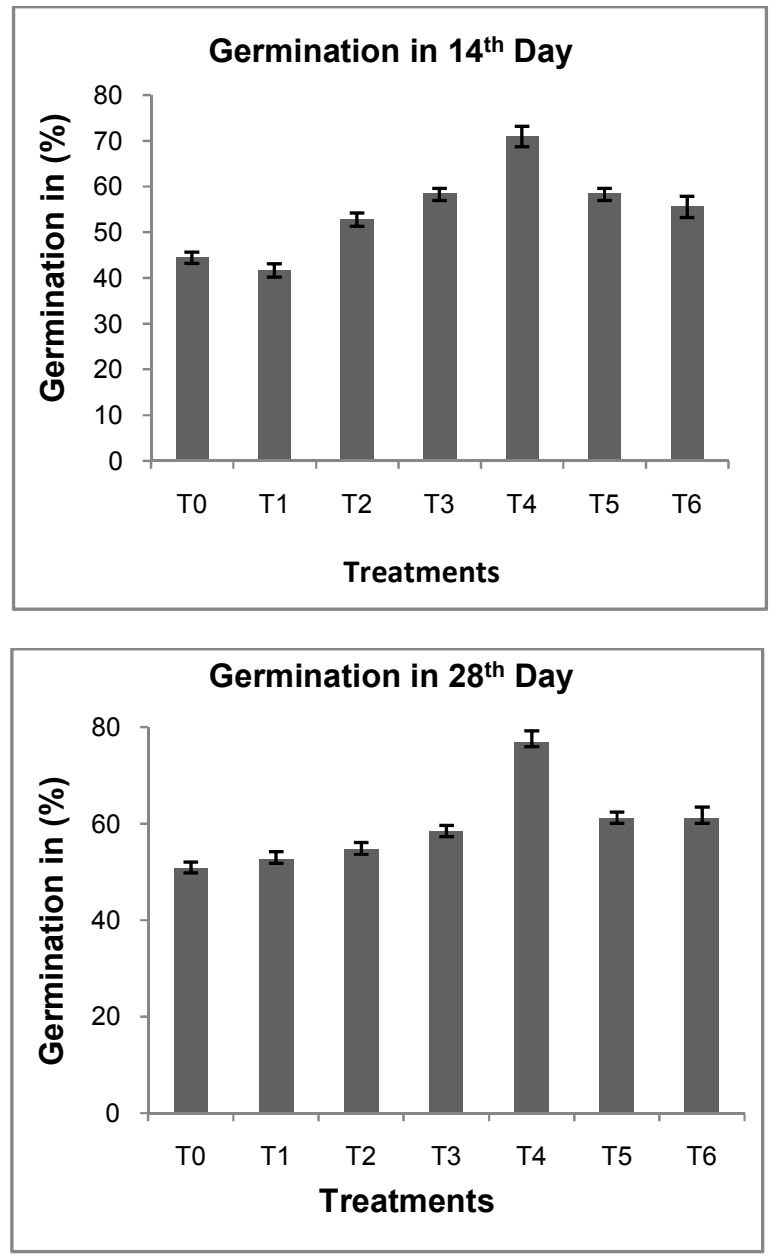

Figure 1: Influence of pancagavya, microherbal fertilizer, biofertilizer, humic acid and FYM on the germination percentage of Cyamopsis tetragonoloba $\left(\mathrm{T}_{0}\right.$-Red loamy soil, $\mathrm{T}_{1}-$ Farmyard manure, $T_{2}$-Humic Acid, $T_{3}$-Panchagavya leaf treatment, $T_{4}-$ Panchagavya soil treatment, $T_{5}-$ Microherbal fertilizer, $\mathrm{T}_{6}$-Biofertilizer (Rhizobium). 
Saritha et al.,

The highest germination percentage in panchagavya might be due to the action of microorganisms and growth promoters (IAA and GA). Kinetin present in coconut water might also be a reason for the increased seed germination. Farmyard manure when applied in Macrophomina phaselina infected soil 10 days after sowing increased the cowpea seed germination (Ratnoo and Bhatngar, 1993). Physicochemical properties of panchagavya revealed that they possess almost all the major nutrients, micronutrients and growth hormones Indole-3-acetic acid (IAA), and Gibberellic acid, (GA) required for crop growth.

\section{Effect of Organic Manures on Biometric Parameters}

The root length was higher in the treatment containing panchagavya soil treatment $\left(T_{4}\right)$ on $30^{\text {th }}$ day $(13.40 \mathrm{~cm})$ and panchagavya leaf treatment $\left(T_{3}\right)$ on $60^{\text {th }}$ day $(23.2 \mathrm{~cm})$ and in farm yard manure $\left(T_{1}\right)$ $26.53 \mathrm{~cm}$ ) on $90^{\text {th }}$ day (Table 1). The shortest root was recorded by control plants $\left(T_{0}\right)$ on $30^{\text {th }}, 60^{\text {th }}$ and $90^{\text {th }}$ day (Table 1). The longest shoot length was observed in the pot of panchagavya leaf treatment $\left(T_{4}\right)$ on $30^{\text {th }}(10.10 \mathrm{~cm}), 60^{\text {th }}(30.37 \mathrm{~cm})$ and $90^{\text {th }}$ $(46.17 \mathrm{~cm})$ days after sowing. The shoot length was least in biofertilizer $\left(T_{6}\right)(5.93 \mathrm{~cm})$ on $30^{\text {th }}$ day and in the control $\left(T_{0}\right)$ on $60^{\text {th }}$ day and $90^{\text {th }}$ day (Table 2). The root length was higher in the panchagavya and FYM soil treatment. This result might be due to the presence of plant nutrients in FYM and it not only adds nutrients but also improves physical condition of soil. The FYM enriched with phosphorus when applied to soybean resulted in increased root length (Ramasamy et al., 2000). This is in accordance with the results that the improvement in root growth due to the favorable soil physical environment created by the addition of organic manures (Durai and Rajagopal, 1983).

More number of leaves was observed on the panchagavya soil treatment $\left(\mathrm{T}_{4}\right)$ and panchagavya leaf treatment $\left(\mathrm{T}_{3}\right)$ (4.34) on $30^{\text {th }}$ day, in the panchagavya leaf treatment $\left(T_{3}\right)$ on $60^{\text {th }}$ day $(10.00)$ and in FYM treated pot $\left(T_{1}\right)$ on $90^{\text {th }}$ day (20.33). The least number of leaves was obtained in $T_{1}, T_{5}$ and $T_{6}$ on $30^{\text {th }}$ day and in control on $60^{\text {th }}$ and $90^{\text {th }}$ day (Table 1). The root volume of the seedlings showed significant variation in different treatments with higher volume in panchagavya soil treatment $\left(\mathrm{T}_{4}\right)$ on $30^{\text {th }}$ day $(0.47 \mathrm{ml})$, in panchagavya leaf treatment $\left(\mathrm{T}_{3}\right)$ on $60^{\text {th }}$ day $(0.87 \mathrm{ml})$ and in farm yard manure $\left(T_{1}\right)$ on $90^{\text {th }}$ day (Table 2 ) followed by panchagavya leaf treatment $\left(T_{3}\right)(2.10 \mathrm{ml})$. The root volume was least in control $\left(T_{0}\right)$ on $30^{\text {th }}, 60^{\text {th }}$ and $90^{\text {th }}$ day (Table 2). Shoot length and number of leaves were also increased with the panchagavya soil treatment. Significantly higher plant heights of rice were recorded with panchagavya spray, which was in accordance with the above results (Yadav and
Sci. Technol. Arts Res. J., April-June 2013, 2(2): 16-21

Lourduraj, 2005 a and b). Since panchagavya was sprayed to foliage, the absorption of nutrients would have been in the higher side, thus encouraging quick growth and increased plant height as noticed in the panchagavya leaf treatment. The use of leaf litter derived millicompost improved the plant height, leaf number and leaf number of Abelmoschus esculentus (Karthigeyan and Alagesan, 2011).

The fresh weight was found to be higher on panchagavya soil treatment $\left(\mathrm{T}_{4}\right)$ on $30^{\text {th }}$ day $(1.04 \mathrm{~g})$ followed by $\left(T_{6}\right)(7.50 \mathrm{~g})$ on $60^{\text {th }}$ day and in panchagavya leaf treatment $\left(T_{3}\right)$ on $90^{\text {th }}$ day $(19.97$ g) followed by FYM $\left(T_{1}\right)(19.70 \mathrm{~g})$. The least fresh weight was obtained in micro-herbal fertilizer $\left(T_{5}\right)$ on $30^{\text {th }}$ day $(0.59 \mathrm{~g})$, control $\left(\mathrm{T}_{0}\right)$ on $60^{\text {th }}$ and $90^{\text {th }}$ day $(3.07,5.18 \mathrm{~g}$ respectively). The maximum dry weight was obtained in the treatments FYM $\left(T_{1}\right)$, panchagavya leaf treatment $\left(T_{3}\right)$ and panchagavya soil treatment $\left(T_{4}\right)(0.14 \mathrm{~g})$ on 30 DAS. Root volume was increased significantly, similar studies were carried out and showed that raw rice weight percentage and husk weight percentages were significantly higher in panchagavya spray (Yadav and Lourduraj, 2006 a and b). Growth promoters and micronutrient content of panchagavya might be the reason for the highest fresh weight of the bean.

It was higher in panchagavya leaf treatment $\left(T_{3}\right)$ $(1.09 \mathrm{~g})$ on $60^{\text {th }}$ day and in FYM $\left(T_{1}\right)$ on $90^{\text {th }}$ day $(5.15 \mathrm{~g})$. The results are in corroboration that application of recommended dose of FYM (20 tonnes/ha) + fertilizers increased the number of leaves per plant and leaf yield (Ravikumar et al., 2006). Number of leaves of green gram and black gram were increased due to panchagavya treatment (De Britto and Girija, 2006). This might be due to the high amount of nutrients in FYM and panchagavya.

\section{Effect of Organic Manure on Vigour Index}

The maximum vigour index was observed in panchagavya soil treatment $\left(T_{4}\right)$ on $30^{\text {th }}(1700), 60^{\text {th }}$ $(3705)$ and $90^{\text {th }}(4070)$ day. The least vigour index was observed in FYM $\left(T_{1}\right)$ on $30^{\text {th }}$ day (Table 2). On $60^{\text {th }}(1594.81)$ and $90^{\text {th }}$ day (1904.28) the least vigour index was obtained in $\mathrm{T}_{0}$ (Table 2). The dry matter of sorghum was significantly more with FYM and nitrogen (Kumar and Balasubramanian, 1986). This can be attributed to the fact that bulk density, porosity, water holding capacity and infiltration rate of soil significantly improved due to the application of organic manures (Maleswar et al., 2000). The increase in vigour index might be due to the presence of different microorganisms in the panchagavya. Bacterial strains isolated from panchagavya formulation when applied to coffee seedlings improved the biomass and vigour index compared to control (Bhat et al., 2004). According to Vijayakumari et al. (2012) the panchagavya, humic acid and micro herbal fertilizer are found to stimulate plant growth and yield. 
Table 1: Influence of panchagavya, microherbal fertilizer, biofertilizer, humic acid and FYM on biometric parameters (root length, shoot length, number of leaves and Root volume) of Cyamopsis tetragonoloba.

\begin{tabular}{|c|c|c|c|c|c|c|c|c|c|c|c|c|}
\hline \multirow{2}{*}{ Treatments } & \multicolumn{3}{|c|}{ Root Length $(\mathrm{cm})$} & \multicolumn{3}{|c|}{ Shoot Length $(\mathrm{cm})$} & \multicolumn{3}{|c|}{$\begin{array}{c}\text { Number of Leaves per } \\
\text { Plant }\end{array}$} & \multicolumn{3}{|c|}{ Root Volume (ml) } \\
\hline & $\begin{array}{l}30^{\text {th }} \\
\text { Day }\end{array}$ & $\begin{array}{l}60^{\text {th }} \\
\text { Day }\end{array}$ & $\begin{array}{l}90^{\text {th }} \\
\text { Day }\end{array}$ & $\begin{array}{l}30^{\text {th }} \\
\text { Day }\end{array}$ & $\begin{array}{l}60^{\text {th }} \\
\text { Day }\end{array}$ & $\begin{array}{l}90^{\text {th }} \\
\text { Day }\end{array}$ & $\begin{array}{l}30^{\text {th }} \\
\text { Day }\end{array}$ & $\begin{array}{l}60^{\text {th }} \\
\text { Day }\end{array}$ & $\begin{array}{l}90^{\text {th }} \\
\text { Day }\end{array}$ & $\begin{array}{l}30^{\text {th }} \\
\text { Day }\end{array}$ & $\begin{array}{l}60^{\text {th }} \\
\text { Day }\end{array}$ & $\begin{array}{l}90^{\text {th }} \\
\text { Day }\end{array}$ \\
\hline $\mathrm{T}_{0}$ & $\begin{array}{r}6.83 \\
\pm 2.1\end{array}$ & $\begin{array}{c}13.46 \\
\pm 4.2\end{array}$ & $\begin{array}{c}13.57 \\
\pm 4.5\end{array}$ & $\begin{array}{c}10.09 \\
\pm 2.5\end{array}$ & $\begin{array}{c}15.77 \\
\pm 2.5\end{array}$ & $\begin{array}{c}22.53 \\
\pm 2.5\end{array}$ & $\begin{array}{l}3.67 \\
\pm 1.5\end{array}$ & $\begin{array}{l}8.33 \\
\pm 1.5\end{array}$ & $\begin{array}{l}9.67 \\
\pm 1.5\end{array}$ & $\begin{array}{c}0.33 \\
\pm 0.01\end{array}$ & $\begin{array}{c}0.47 \\
\pm 0.07\end{array}$ & $\begin{array}{r}0.70 \\
\pm 0.25\end{array}$ \\
\hline $\mathrm{T}_{1}$ & $\begin{array}{l}9.87 \\
\pm 2.5\end{array}$ & $\begin{array}{c}21.57 \\
\pm 3.5\end{array}$ & $\begin{array}{c}26.53 \\
\pm 5.6\end{array}$ & $\begin{array}{l}8.53 \\
\pm 1.9\end{array}$ & $\begin{array}{l}17.87 \\
\pm 2.5\end{array}$ & $\begin{array}{l}42.30 \\
\pm 6.4\end{array}$ & $\begin{array}{c}3.67 \\
\pm 1.00\end{array}$ & $\begin{array}{l}9.33 \\
\pm 2.5\end{array}$ & $\begin{array}{c}20.33 \\
\pm 1.8\end{array}$ & $\begin{array}{l}0.43 \\
\pm 0.1\end{array}$ & $\begin{array}{l}0.60 \\
\pm 0.1\end{array}$ & $\begin{array}{c}2.20 \\
\pm 0.97\end{array}$ \\
\hline$T_{2}$ & $\begin{array}{l}11.50 \\
\pm 3.5\end{array}$ & $\begin{array}{l}19.50 \\
\pm 2.5\end{array}$ & $\begin{array}{c}23.07 \\
\pm 7.3\end{array}$ & $\begin{array}{l}7.17 \\
\pm 1.5\end{array}$ & $\begin{array}{l}17.03 \\
\pm 2.5\end{array}$ & $\begin{array}{l}24.37 \\
\pm 5.5\end{array}$ & $\begin{array}{l}4.00 \\
\pm 1.5\end{array}$ & $\begin{array}{l}8.67 \\
\pm 1.4\end{array}$ & $\begin{array}{l}15.00 \\
\pm 2.1\end{array}$ & $\begin{array}{l}0.40 \\
\pm 0.1\end{array}$ & $\begin{array}{c}0.53 \\
\pm 0.09\end{array}$ & $\begin{array}{c}1.67 \\
\pm 0.95\end{array}$ \\
\hline $\mathrm{T}_{3}$ & $\begin{array}{l}6.83 \\
\pm 1.7\end{array}$ & $\begin{array}{c}23.21 \\
\pm 3.8\end{array}$ & $\begin{array}{c}23.27 \\
\pm 5.6\end{array}$ & $\begin{array}{l}10.10 \\
\pm 2.5\end{array}$ & $\begin{array}{l}30.37 \\
\pm 5.5\end{array}$ & $\begin{array}{l}46.17 \\
\pm\end{array}$ & $\begin{array}{l}4.34 \\
\pm 2.3\end{array}$ & $\begin{array}{c}10.00 \\
\pm 1.4\end{array}$ & $\begin{array}{l}18.33 \\
\pm 3.5\end{array}$ & $\begin{array}{c}0.33 \\
\pm 0.09\end{array}$ & $\begin{array}{c}0.87 \\
\pm 0.09\end{array}$ & $\begin{array}{l}2.10 \\
\pm 0.9\end{array}$ \\
\hline $\mathrm{T}_{4}$ & $\begin{array}{l}13.40 \\
\pm 1.2\end{array}$ & $\begin{array}{c}22.77 \\
\pm 4.5\end{array}$ & $\begin{array}{c}23.07 \\
\pm 3.5\end{array}$ & $\begin{array}{l}9.28 \\
\pm 2.2\end{array}$ & $\begin{array}{l}26.63 \\
\pm 4.7\end{array}$ & $\begin{array}{c}31.20 \\
\pm 5.6\end{array}$ & $\begin{array}{l}4.34 \\
\pm 2.2\end{array}$ & $\begin{array}{l}9.67 \\
\pm 1.5\end{array}$ & $\begin{array}{c}14.00 \\
\pm 2.5\end{array}$ & $\begin{array}{l}0.47 \\
\pm 0.1\end{array}$ & $\begin{array}{c}0.70 \\
\pm 0.05\end{array}$ & $\begin{array}{c}1.47 \\
\pm 0.25\end{array}$ \\
\hline$T_{5}$ & $\begin{array}{l}8.90 \\
\pm 1.7\end{array}$ & $\begin{array}{l}16.84 \\
\pm 4.7\end{array}$ & $\begin{array}{l}16.87 \\
\pm 2.5\end{array}$ & $\begin{array}{l}7.07 \\
\pm 1.3\end{array}$ & $\begin{array}{l}15.78 \\
\pm 3.7\end{array}$ & $\begin{array}{c}27.70 \\
\pm 4.6\end{array}$ & $\begin{array}{l}3.67 \\
\pm 1.5\end{array}$ & $\begin{array}{l}8.34 \\
\pm 2.2\end{array}$ & $\begin{array}{c}13.00 \\
\pm 1.6\end{array}$ & $\begin{array}{c}0.43 \\
\pm 0.09\end{array}$ & $\begin{array}{c}0.57 \\
\pm 0.04\end{array}$ & $\begin{array}{l}1.20 \\
\pm 0.1\end{array}$ \\
\hline$T_{6}$ & $\begin{array}{l}9.97 \\
\pm 1.4\end{array}$ & $\begin{array}{c}19.53 \\
\pm 3.5\end{array}$ & $\begin{array}{c}21.90 \\
\pm 1.5\end{array}$ & $\begin{array}{c}5.93 \\
\pm 1.00\end{array}$ & $\begin{array}{c}21.43 \\
\pm 2.8\end{array}$ & $\begin{array}{c}30.37 \\
\pm 6.5\end{array}$ & $\begin{array}{l}3.67 \\
\pm 0.7\end{array}$ & $\begin{array}{l}8.67 \\
\pm 3.5\end{array}$ & $\begin{array}{c}14.00 \\
\pm 2.7\end{array}$ & $\begin{array}{c}0.43 \\
\pm 0.09\end{array}$ & $\begin{array}{c}0.77 \\
\pm 0.01\end{array}$ & $\begin{array}{r}1.90 \\
\pm 0.5\end{array}$ \\
\hline $\begin{array}{c}\text { SEd } \\
\text { CD }(P=0.01)\end{array}$ & $\begin{array}{r}1.61 \\
4.93^{\star *}\end{array}$ & $\begin{array}{l}1.07 \\
3.26^{* *}\end{array}$ & $\begin{array}{l}2.66 \\
8.14^{\star *}\end{array}$ & $\begin{array}{l}1.18 \\
3.61^{*}\end{array}$ & $\begin{array}{l}1.13 \\
3.45^{\text {** }}\end{array}$ & $\begin{array}{l}3.12 \\
9.54^{\star *}\end{array}$ & $\begin{array}{l}0.009 \\
0.03^{* *}\end{array}$ & 0.02 & $\begin{array}{l}1.89 \\
5.78^{\star *}\end{array}$ & 0.02 & $\begin{array}{l}0.06 \\
0.20^{\text {** }}\end{array}$ & $\begin{array}{l}0.15 \\
0.46^{* *}\end{array}$ \\
\hline
\end{tabular}

Table 2: Influence of panchagavya, micro-herbal fertilizer, biofertilizer, humic acid and FYM on the fresh weight, dry weight and vigour index of Cyamopsis tetragonoloba.

\begin{tabular}{|c|c|c|c|c|c|c|c|c|c|}
\hline \multirow[b]{2}{*}{ Treatments } & \multicolumn{3}{|c|}{ Fresh Weight (g) } & \multicolumn{3}{|c|}{ Dry Weight (g) } & \multicolumn{3}{|c|}{ Vigour Index } \\
\hline & $\begin{array}{l}30^{\text {th }} \\
\text { Day }\end{array}$ & $\begin{array}{l}60^{\text {th }} \\
\text { Day }\end{array}$ & $\begin{array}{l}90^{\text {th }} \\
\text { Day }\end{array}$ & $\begin{array}{l}30^{\text {th }} \\
\text { Day }\end{array}$ & $\begin{array}{l}60^{\mathrm{th}} \\
\text { Day }\end{array}$ & $\begin{array}{l}90^{\text {th }} \\
\text { Day }\end{array}$ & $\begin{array}{l}30^{\text {th }} \\
\text { Day }\end{array}$ & $\begin{array}{l}60^{\text {th }} \\
\text { Day }\end{array}$ & $\begin{array}{l}90^{\text {th }} \\
\text { Day }\end{array}$ \\
\hline$T_{0}$ & $\begin{array}{c}1.03 \\
\pm 0.04\end{array}$ & $\begin{array}{l}3.07 \\
\pm 0.5\end{array}$ & $\begin{array}{l}5.18 \\
\pm 1.5\end{array}$ & $\begin{array}{l}0.10 \\
\pm 0.5\end{array}$ & $\begin{array}{c}0.64 \\
\pm 0.12\end{array}$ & $\begin{array}{c}1.43 \\
\pm 0.05\end{array}$ & $\begin{array}{c}893.24 \\
\pm 120\end{array}$ & $\begin{array}{c}1594.81 \\
\pm 289\end{array}$ & $\begin{array}{c}1904.28 \\
\pm 127\end{array}$ \\
\hline $\mathrm{T}_{1}$ & $\begin{array}{c}0.87 \\
\pm 0.02\end{array}$ & $\begin{array}{l}4.47 \\
\pm 1.5\end{array}$ & $\begin{array}{l}19.70 \\
\pm 3.6\end{array}$ & $\begin{array}{c}0.14 \\
\pm 0.05\end{array}$ & $\begin{array}{l}0.84 \\
\pm 0.1\end{array}$ & $\begin{array}{l}5.15 \\
\pm 1.5\end{array}$ & $\begin{array}{c}817.33 \\
\pm 95\end{array}$ & $\begin{array}{c}1751.63 \\
\pm 376\end{array}$ & $\begin{array}{c}3057.57 \\
\pm 187\end{array}$ \\
\hline$T_{2}$ & $\begin{array}{c}0.79 \\
\pm 0.01\end{array}$ & $\begin{array}{l}3.46 \\
\pm 1.5\end{array}$ & $\begin{array}{l}9.91 \\
\pm 2.1\end{array}$ & $\begin{array}{c}0.11 \\
\pm 0.05\end{array}$ & $\begin{array}{c}0.71 \\
\pm 0.25\end{array}$ & $\begin{array}{l}2.23 \\
\pm 0.9\end{array}$ & $\begin{array}{c}1088.83 \\
\pm 127\end{array}$ & $\begin{array}{c}2130.99 \\
\pm 287\end{array}$ & $\begin{array}{c}2766.79 \\
\pm 156\end{array}$ \\
\hline$T_{3}$ & $\begin{array}{r}1.03 \\
\pm 0.4\end{array}$ & $\begin{array}{c}7.82 \\
\pm 1.45\end{array}$ & $\begin{array}{l}19.97 \\
\pm 2.5\end{array}$ & $\begin{array}{c}0.14 \\
\pm 0.001\end{array}$ & $\begin{array}{c}1.09 \\
\pm 0.09\end{array}$ & $\begin{array}{l}4.42 \\
\pm 1.4\end{array}$ & $\begin{array}{c}987.72 \\
\pm 89\end{array}$ & $\begin{array}{c}3453.14 \\
\pm 168\end{array}$ & $\begin{array}{c}4050.05 \\
\pm 324\end{array}$ \\
\hline $\mathrm{T}_{4}$ & $\begin{array}{c}1.04 \\
\pm 0.45\end{array}$ & $\begin{array}{c}5.88 \\
\pm 0.95\end{array}$ & $\begin{array}{l}11.63 \\
\pm 1.5\end{array}$ & $\begin{array}{c}0.14 \\
\pm 0.05\end{array}$ & $\begin{array}{c}0.88 \\
\pm 0.95\end{array}$ & $\begin{array}{c}3.04 \\
\pm 0.65\end{array}$ & $\begin{array}{c}1700.00 \\
\pm 201\end{array}$ & $\begin{array}{c}3705.00 \\
\pm 317\end{array}$ & $\begin{array}{c}4070.00 \\
\pm 333\end{array}$ \\
\hline$T_{5}$ & $\begin{array}{c}0.59 \\
\pm 0.09\end{array}$ & $\begin{array}{l}3.63 \\
\pm 1.1\end{array}$ & $\begin{array}{l}9.51 \\
\pm 0.9\end{array}$ & $\begin{array}{c}0.10 \\
\pm 0.02\end{array}$ & $\begin{array}{l}0.73 \\
\pm 0.5\end{array}$ & $\begin{array}{c}1.99 \\
\pm 0.95\end{array}$ & $\begin{array}{c}975.25 \\
\pm 215\end{array}$ & $\begin{array}{c}2196.84 \\
\pm 217\end{array}$ & $\begin{array}{c}2722.13 \\
\pm 212\end{array}$ \\
\hline$T_{6}$ & $\begin{array}{c}0.69 \\
\pm 0.05\end{array}$ & $\begin{array}{c}7.50 \\
\pm 0.09\end{array}$ & $\begin{array}{l}11.79 \\
\pm 1.5\end{array}$ & $\begin{array}{c}0.11 \\
\pm 0.01\end{array}$ & $\begin{array}{c}1.05 \\
\pm 0.05\end{array}$ & $\begin{array}{l}3.00 \\
\pm 0.5\end{array}$ & $\begin{array}{c}971.17 \\
\pm 115\end{array}$ & $\begin{array}{c}2502.24 \\
\pm 298\end{array}$ & $\begin{array}{c}3192.45 \\
\pm 221\end{array}$ \\
\hline $\begin{array}{l}\text { SEd } \\
C D(P=0.01)\end{array}$ & $\begin{array}{l}0.14 \\
0.43^{*}\end{array}$ & $\begin{array}{c}0.68 \\
2.09^{* *}\end{array}$ & $\begin{array}{c}1.60 \\
4.90^{\star *}\end{array}$ & $\begin{array}{l}0.02 \\
0.05^{*}\end{array}$ & $\begin{array}{c}0.09 \\
0.26^{\star *}\end{array}$ & $\begin{array}{c}0.68 \\
2.06^{* *}\end{array}$ & $\begin{array}{c}154.13 \\
470.82^{\star *}\end{array}$ & $\begin{array}{c}116.15 \\
354.79^{* *}\end{array}$ & $\begin{array}{c}300.43 \\
917.72^{\star *}\end{array}$ \\
\hline
\end{tabular}


Saritha et al.,

\section{CONCLUSION}

Sustainable agriculture is the need of the hour and it will maintain the cycles of input-output and ecosystem balance. Because of over emphasis on chemical farming deterioration of land took place and improvement in productivity slowed down along with very serious soil and water pollution problems. Considering the implications of chemical usage in agriculture, it is high time to suitably modify the recent agro-technologies to best suit the need with an overall view of restoring the ecosystem, preserving the biodiversity and ultimately human health and wealth. Therefore, there is a considerable demand and scope for development of "organic technologies" either individually or as a package. The concept of organic farming actually seeks to re-establish the balance of energy in nature without using the chemical fertilizers and pesticides. This farming system is mainly based upon traditional methods/techniques derived on sound ecological principles. The ill effects of chemicals used in agriculture have changed the mindset of some consumers of different countries who are now buying organic with high premium for health.

\section{ACKNOWLEDGEMENTS}

The authors are thankful to Department of Botany, Avinashilingam University for Women Coimbatore, Tamil Naidu, India for providing the facilities and Haramaya University, Ethiopia is highly acknowledged.

\section{REFERENCES}

Bhat, S.S., Vinu A.K., Naidu, R. (2004). Association of diverse groups of bacteria with Panchagavya and their effect on growth promotion of coffee seedlings. The Association for Science and Information on Coffee (ASIC): Proceedings of ASIC Conferences $-20^{\text {th }}$ Colloquium.

Bhattacharya, P., Chakraborty, G. (2005). Current status of organic farming in India and other countries. Indian Journal of Fertilizer 1: 111-123.

Bindhu, S., Vijayakumari, B., Hiranmai Yadav, R. (2013). Utilization of Biodynamic Farming to Improve Quality Attributes of Soybean (Glycine max L. var. Co. Soy). Science, Technology and Arts Research Journal 2: 3235.

De Britto, A., Girija, L.S. (2006). Investigations on the effect of organic and inorganic farming methods on black gram and green gram. Indian Journal of Agricultural Research 40: 204-207.

Durai, R., Rajagopal, A. (1983). In: Proc. National Seminar on Utilisation of Organic Wastes, ACandRI, Madurai, pp. 104-109.
Sci. Technol. Arts Res. J., April-June 2013, 2(2): 16-21

Gopalan, C., Ramasastri, B.V., Balasubramanian, S.C. (2000). Proximate principles: Common foods. In: Narasinga Rao, B.C., Pant, K.C. and Deosthale, Y.G. (Eds.), Nutritive value of Indian foods (Revised and updated edition) (pp. 53-55). Hyderabad, India: National Institute of Nutrition, ICMR.

Gupta, R.D., Kher, D., Jalali, V.K. (2005). Organic farming: Concept and its prospective in Jammu and Kashmir. Journal of Research 1: 25-37.

Javed, S., Aruna Panwar. (2013). Effect of biofertilisers, vermicompost and chemical fertilizer on different biochemical parameters of Glycine max and Vigna mungo. Recent Research in Science and Technology 5(1): 40-44.

Karthigeyan, M. and Alagesan, P. (2011). Millipede composting: A novel method for organic waste recycling. Recent Research in Science and Technology 3: 62-67.

Kumar, K., Balasubramanian, B. (1986). Field response of rice to Azospirillum biofertilizer. Current Research 15:74-76.

Maleswar, G.U., Badole, S.B., Mali, C.V., Siddique, M.B., Ismail, S. (2000). Influence of fly ash with and without FYM and fertilizer on physico-chemical properties of sunflower and cotton growing soils. Annals of Agricultural Research 21: 187-191.

Ramasamy, N., Sankaran, N., Ganapathy, N. (2000). Phosphorus boosts soybean yield. The Hindu Science and Technology 8.

Ratnoo, R.S., Bhatngar, M.S. (1993). Neem cake in disease control. Indian Journal of Mycology and Plant Pathology 23: 186-188.

Ravikumar, A., Narayanaswamy, T.K., Bhaskar, R.N., Naika, R. (2006). Influence of various nitrogenous sources through organic manures on growth and yield attributes of Mulberry. Mysore Journal of Agricultural Science 40: 194-198.

Vijayakumari, B., Hiranmai Yadav, R., Gowri, P., Kandari, L.S. (2012). Effect of Panchagavya, Humic acid and Micro herbal Fertilizer on the Yield and Post Harvest Soil of Soya Bean (Glycine max L.). Asian Journal of Plant Science 11: 83-86.

Yadav, B.K., Lourduraj, A.C. (2005a). Effect of organic manures and panchagavya spray on growth attributes and yield of rice (Oriza sativa L.) Indian Journal of Environment and Ecological Planning 10: 617-623.

Yadav, B.K., Lourduraj, A.C. (2005b). Effect of organic manures and panchagavyga spray on nutrient composition of raw rice (Oriza sativa L.) Indian Journal of Environment and Ecological Planning 10: 873-878.

Yadav, B.K., Lourduraj, A.C. (2006a) Effect of organic manures and panchagavya spray on yield attributes, yield and economics of rice (Oryza sativa L.). Crop Research 31: 1-5.

Yadav, B.K., Lourduraj, A.C. (2006b) Effect of organic manures and panchagavya spray on rice (Oryza sativa L.) quality. Crop Research 31: 6-10. 